\title{
Fertilizer circulation and nitrogen balance in the agrophytocenosis of sugar beet when acidizing typical chernozem (study with ${ }^{15} \mathrm{n}$ )
}

\author{
A.S. Avilov ${ }^{1, *}$, N.Ya. Shmyreva ${ }^{2}, A . A$. Zavalin $^{2}$, and O.A. Sokolov ${ }^{2}$ \\ ${ }^{1}$ Belgorod Center for Agrochemical Service, Belgorod, Russian Federation \\ ${ }^{2}$ Federal State Budgetary Scientific Institution All-Russian Research Institute of Agricultural Chemistry \\ named after D.N. Pryanishnikova, Moscow, Russian Federation
}

\begin{abstract}
The studies were carried out under the conditions of a microfield experiment on typical chernozem (Belgorod region) with two soils ( $\mathrm{pH} 5.0$ and 6.5) with the addition of urea (enriched in ${ }^{15} \mathrm{~N}, 17.1$ at. \%) And effluents from a pig-breeding complex (PSC) at doses of 6 and $12 \mathrm{~g} \mathrm{~N} / \mathrm{m}^{2}$ (against the background of phosphate and potash fertilizers, $\mathrm{P}_{6} \mathrm{~K}_{6}$ ). The largest amount of nitrogen was consumed by sugar beets with the combined introduction of CCA and urea $\left(25.8 \mathrm{~g} \mathrm{~N} / \mathrm{m}^{2}\right)$. When the soil was acidified to pHsalt 5.0 , the consumption of nitrogen in mineral fertilizers decreased by $15-18 \%$, soil nitrogen - by $21-52 \%$, and waste nitrogen - by $16 \%$. At the same time, the immobilization of nitrogen in the fertilizer decreased by $13-18 \%$, and the loss of gaseous nitrogen compounds increased by $47-108 \%$. The effluent from the pig-breeding complex increased the immobilization of nitrogen in mineral fertilizers (by 38-46\%) and reduced gaseous nitrogen losses (by 22$44 \%$ ). The highest stability and productivity (root crop yield $1654 \mathrm{~g} / \mathrm{m}^{2}$, tops yield $239 \mathrm{~g} / \mathrm{m} 2$ ) was exhibited by agrophytocenosis on soil with $\mathrm{pH} 6.5$ with the combined application of CCA and urea. When the soil solution was acidified to $\mathrm{pH} 5.0$, the yield of beet root crops decreased by $30 \%$ and the yield of tops - by $24 \%$. On soil with $\mathrm{pH} 5.0$, fertilizers increased the sugar content in root crops by $0.2-1.3 \%$, on soil with $\mathrm{pH} 6.5$, they decreased by $1.3-2.0 \%$.
\end{abstract}

\section{Introduction}

Among the environmental problems characteristic of agriculture in the Central Black Earth Region (CCR) of Russia, the following can be distinguished: the development of erosion processes, low soil supply with mobile forms of many microelements, pollution with heavy metals, dehumification, intensive acidification of the soil solution [1-4]. As a result of prolonged acidic nitrogen fertilizers' use and the fallout of acid precipitation, the decalcification of the soil SAC increases, the amount of absorbed bases and the humus content decreases, the hydrolytic acidity increases and the structure of the arable layer deteriorates.

\footnotetext{
Corresponding author: agrohim_31@mail.ru
} 
Sugar beet (the main intensive-type crop in the Chernozem zone) consumes up to 200$230 \mathrm{~kg} \mathrm{~N} / \mathrm{ha}$ at a cost of up to $5.0-5.3 \mathrm{~kg} \mathrm{~N} / \mathrm{t}$ of production [5-7]. Sugar beets are characterized by optimal productivity at a narrow $\mathrm{pH}$ value of 6.5-7.5.

A change in the reaction of a soil solution affects the direction and intensity of nitrogen transformation in the soil, its availability and consumption by plants $[1,8]$. As for sugar beet, these questions remain unexplored and open.

The purpose of the research was to determine the parameters of the fertilizer nitrogen cycle and soil nitrogen fluxes during the cultivation of sugar beets and acidification of chernozem soil.

\section{Materials and Methods}

The studies were carried out in a microfield experiment in vessels with no bottom (area $45 \times 23$ $\mathrm{cm}$, depth $30 \mathrm{~cm}$ ) at the experimental site of the State Center of Agrochemical Service "Belgorodsky". Typical chernozem differing in the reaction of soil traces was used. Agrochemical characteristics of soil No.1: $\mathrm{pH}_{\text {salt }} 6.5, \mathrm{H}_{\mathrm{g}}$ (according to Kappen) - $1.32 \mathrm{mmol} / 100 \mathrm{~g}$ of soil, the content of exchange $\mathrm{Ca}^{+}-26.7, \mathrm{Mg}^{2+}-2.81 \mathrm{mmol} / 100 \mathrm{~g}$ of soil, the sum of absorbed bases (according to Kappen-Gilkowitz) - $42.6 \mathrm{mmol} / 100 \mathrm{~g}$ of soil, humus content (according to Tyurin) - $5.0 \%$, total nitrogen (according to the Kjeldahl-Jodlbauer method) - $0.23 \%$, mobile forms of phosphorus and potassium (according to Chirikov) - 118 and $140 \mathrm{mg} / \mathrm{kg}$, respectively.

Agrochemical characteristics of soil No.2: $\mathrm{pH}_{\text {salt }} 5.0, \mathrm{~N}_{\mathrm{g}}$ (according to Kappen) - 5.81 $\mathrm{mmol} / 100 \mathrm{~g}$ of soil, the content of exchange $\mathrm{Ca}^{+}-19.5, \mathrm{Mg}^{2+}-2.52 \mathrm{mmol} / 100 \mathrm{~g}$ of soil, the sum of absorbed bases (according to Kappen-Gilkowitz) - $35.6 \mathrm{mmol} / 100 \mathrm{~g}$ of soil, humus content (according to Tyurin) - 5.2\%, total nitrogen (according to the Kjeldahl-Jodlbauer method) $-0.21 \%$, mobile forms of phosphorus and potassium (according to Chirikov) - 110 and $105 \mathrm{mg} / \mathrm{kg}$, respectively.

The experimental scheme included the following options (fertilizers' doses, $\mathrm{g} / \mathrm{m}^{2}$ ): $1 . \mathrm{P}_{6} \mathrm{~K}_{6}$ - background (control); 2. Background $+{ }^{15} \mathrm{~N}_{12} ; 3$. Background $+\mathrm{PBE}_{6}+{ }^{15} \mathrm{~N}_{6} ; 4$. Background $+\mathrm{PBE}_{12}$ (equivalent to $\mathrm{N}_{12}$ ). Fertilizers were applied before sowing sugar beet (variety XM1820). Double superphosphate and potassium chloride were added as background. Urea was applied as nitrogen fertilizer (initial enrichment with ${ }^{15} \mathrm{~N}$ isotope, 17.1 at.\%). As an organic fertilizer, the pig-breeding complex effluent (PBE) was applied, \%: dry matter - 1.2; humidity - 98.6; $\mathrm{pH}_{\text {salt }}-7.8$; ash content -0.42 ; organic matter -0.75 ; total nitrogen -0.21 ; phosphorus - 0.08; potassium - 0.13; calcium - 0.04; magnesium - 0.01 . The total nitrogen and its isotopic composition of soil and plant samples after harvesting were determined using an elemental analyzer by the dry ashing method according to Dumas Flesh EA, model 1112 on a Delta Advantage mass spectrometer.

Soil nitrogen fluxes and parameters of their stability were determined according to the method described in [9-11]. The sugar content in root crops was determined by the method (GOST 53036-2008). The data on the yield of root crops and tops, sugar content in root crops were processed by the variance analysis (STAT VNIIA), the significance of differences (difference) was assessed by Fisher's F-test.

\section{Results and Discussion}

The largest amount of nitrogen was consumed by sugar beets with the combined application of effluent and mineral fertilizers at $\mathrm{pH} 6.5$ of the soil solution (Table 1). With a decrease in 
$\mathrm{pH}$ to 5.0 , nitrogen consumption by plants decreased by $14-45 \%$. At the same time, the consumption of nitrogen in mineral fertilizers fell by $15-18 \%$, soil nitrogen - by $21-52 \%$, effluent nitrogen - by $16 \%$. In our studies, the use of effluent nitrogen (PBE) at the level of $16-19 \%$ of the applied dose was accepted based on the data obtained in studies with labeled ${ }^{15} \mathrm{~N}$ litterfree cattle manure $[13,14]$.

The nitrogen consumption of fertilizers by plants during the effluent introduction decreased at $\mathrm{pH} 5.0$ by $54 \%$, at $\mathrm{pH} 6.5$ - by $56 \%$, while the assimilation of soil nitrogen by beets increased at $\mathrm{pH} 5.0$ by $99 \%$, and at $\mathrm{pH} 6.5$ - by $21 \%$ compared with the use of some mineral nitrogen fertilizers.

With the combined application of organic and mineral fertilizers, the immobilization of mineral fertilizers' nitrogen (by 39-45\%) and the mineralization of nitrogen from the effluent of the pig-breeding complex (by 21-42\%) increased simultaneously. This is due to that the $\mathrm{C}: \mathrm{N}$ ratio in the soil changes with the introduction of $\mathrm{PBE}$ [15-18]. Active immobilization of nitrogen in the soil prevails at a $\mathrm{C}: \mathrm{N}$ ratio $>18$ [8]. At $\mathrm{pH} 5.0$, the use of fertilizer's nitrogen by plants is significantly reduced (by $15-18 \%$ ) and its immobilization, which occurs due to an increase in the release of gaseous nitrogen-containing compounds (by 47-108\%) (Table 2).

Table 1. Consumption of nitrogen in mineral, organic fertilizers and soil nitrogen by sugar beet during acidification of typical chernozem.

\begin{tabular}{|c|c|c|c|c|c|c|c|}
\hline \multirow[b]{2}{*}{ Option } & \multirow{2}{*}{$\begin{array}{c}\text { Total } \\
\text { removal } \\
\mathrm{N}, \\
\text { g/vessel }\end{array}$} & \multicolumn{2}{|c|}{ Fertilizer nitrogen } & \multicolumn{2}{|c|}{ Soil nitrogen } & \multicolumn{2}{|c|}{ Nitrogen PBE } \\
\hline & & $\mathrm{g} /$ vessel & $\begin{array}{c}\text { \% of re- } \\
\text { moval } \\
\mathrm{N}\end{array}$ & $\mathrm{g} /$ vessel & $\begin{array}{c}\% \text { of re- } \\
\text { moval } \\
\mathrm{N}\end{array}$ & $\mathrm{g} /$ vessel & $\begin{array}{c}\text { \% of re- } \\
\text { moval } \\
\mathrm{N}\end{array}$ \\
\hline \multicolumn{8}{|c|}{$\mathrm{pH} 5.0$} \\
\hline $\mathrm{P}_{6} \mathrm{~K}_{6}-$ background & 9.28 & - & - & 9.28 & 100 & - & - \\
\hline $\begin{array}{l}\text { Background + } \\
{ }^{15} \mathrm{~N}_{12}\end{array}$ & 12.92 & 4.03 & 31 & 8.89 & 69 & - & - \\
\hline $\begin{array}{l}\text { Background + } \\
\text { PBE } 6_{6}+{ }^{15} \mathrm{~N}_{6}\end{array}$ & 20.51 & 1.84 & 9 & 17.71 & 86 & 0.96 & 5 \\
\hline $\begin{array}{l}\text { Background + } \\
\text { PBE }_{12} \text { (equiv. to } \\
\mathrm{N}_{12} \text { ) }\end{array}$ & 12.03 & - & - & 10.11 & 84 & 1.92 & 16 \\
\hline \multicolumn{8}{|c|}{ pH 6.5} \\
\hline $\mathrm{P}_{6} \mathrm{~K}_{6}-$ background & 11.17 & - & - & 11.17 & 100 & - & - \\
\hline $\begin{array}{l}\text { Background + } \\
{ }^{15} \mathrm{~N}_{12}\end{array}$ & 23.42 & 4.92 & 21 & 18.50 & 79 & - & - \\
\hline $\begin{array}{l}\text { Background + } \\
\text { PBE }_{6}+{ }^{15} \mathrm{~N}_{6}\end{array}$ & 25.78 & 2.17 & 8 & 22.47 & 87 & 1.14 & 5 \\
\hline $\begin{array}{l}\text { Background }+ \\
\text { PBE } 12 \text { (equiv. to } \\
\mathrm{N}_{12} \text { ) }\end{array}$ & 19.34 & - & - & 17.06 & 88 & 2.28 & 12 \\
\hline
\end{tabular}

Table 2. Fertilizer nitrogen fluxes and balance during cultivation of sugar beet and acidification of typical chernozem.

\begin{tabular}{|c|c|c|c|c|c|c|}
\hline \multirow{2}{*}{ Options } & \multicolumn{2}{|c|}{$\begin{array}{c}\text { Usage } \\
\text { by plants }\end{array}$} & \multicolumn{2}{c|}{$\begin{array}{c}\text { Immobilized in a } 40 \\
\text { cm layer }\end{array}$} & \multicolumn{2}{c|}{$\begin{array}{c}\text { Gaseous } \\
\text { losses }\end{array}$} \\
\cline { 2 - 7 } & $\mathrm{g} /$ vessel & $\begin{array}{c}\% \text { of } \\
\text { dose } \mathrm{N}\end{array}$ & $\mathrm{g} /$ vessel & $\begin{array}{c}\% \text { of } \\
\text { dose } \mathrm{N}\end{array}$ & $\mathrm{g} /$ vessel & $\begin{array}{c}\% \text { of } \\
\text { dose } \mathrm{N}\end{array}$ \\
\hline \multicolumn{8}{|c|}{$\mathrm{pH} 5.0$} \\
\hline $\mathrm{P}_{6} \mathrm{~K}_{6}$ - background & - & - & - & - & - & - \\
\hline Background $+{ }^{15} \mathrm{~N}_{12}$ & 4.03 & 33.6 & 3.50 & 29.2 & 4.46 & 37.2 \\
\hline
\end{tabular}




\begin{tabular}{|l|c|c|c|c|c|c|}
\hline $\begin{array}{l}\text { Background + } \mathrm{PBE}_{6}+ \\
{ }^{15} \mathrm{~N}_{6}\end{array}$ & 1.84 & 30.6 & 2.42 & 40.3 & 1.74 & 29.1 \\
\hline $\begin{array}{l}\text { Background + } \mathrm{PBE}_{12} \\
\text { (equiv. to } \mathrm{N}_{12} \text { ) }\end{array}$ & - & - & - & - & - & - \\
\hline \multicolumn{7}{|c|}{$\mathrm{pH} 6.5$} \\
\hline $\mathrm{P}_{6} \mathrm{~K}_{6}$ - background & - & - & - & - & - & - \\
\hline Background $+{ }^{15} \mathrm{~N}_{12}$ & 4.92 & 41.0 & 4.04 & 33.7 & 3.04 & 25.3 \\
\hline $\begin{array}{l}\text { Background + } \mathrm{PBE}_{6}+ \\
{ }^{15} \mathrm{~N}_{6}\end{array}$ & 2.17 & 36.1 & 2.96 & 49.4 & 0.87 & 14.5 \\
\hline $\begin{array}{l}\text { Background + } \mathrm{PBE}_{12} \\
\text { (equiv. to } \mathrm{N}_{12} \text { ) }\end{array}$ & - & - & - & - & - & - \\
\hline
\end{tabular}

Thanks to the method of ${ }^{15} \mathrm{~N}$ isotope indication, it is possible to determine the degree of nitrogen participation in the formation of agrophytocenosis sustainability development [8, $11,12]$. It is the fluxes of soil nitrogen that determine the degree of stable agrophytocenosis functioning, since it is this that represents $70-80 \%$ of the total removal of nitrogen by plants.

The direction and intensity of the nitrogen cycle in the agrophytocenosis depends on the ratio of carbon and nitrogen in the fertilizer [8, 16-18]. With the introduction of pig-breeding complex effluent (ratio $\mathrm{C}: \mathrm{N}=5-10: 1$ ), the immobilization of soil nitrogen increased significantly (1.4-3.6 times). At the same time, gaseous nitrogen losses decreased by $44 \%$ at $\mathrm{pH}$ 5.0 , they increased by $39 \%$ while at $\mathrm{pH} 6.5$ (Table 3 ). At $\mathrm{pH} 5.0$, the mineralization and net mineralization of soil nitrogen decreased, while at $\mathrm{pH} 6.5$ it increased. At the same time, the reimmobilization of soil nitrogen under the influence of effluent increased by $18-28 \%$.

The nitrogen of the applied fertilizers is actively included in the intrasoil cycle of nitrogen transformation and determines the functioning mode of the agrophytocenosis [11].

According to the accepted classification, the agrophytocenosis of sugar beet on chernozem with pH 6.5 is in the stress zone and functions under the permissible regime (Table 4). With a decrease in $\mathrm{pH}$ to 5.0, agrophytocenosis functions in the resistance zone at the maximum permissible mode. When PBE was applied (against the background of nitrogen fertilizers), the stability of agrophytocenosis increased to a stress zone at an acceptable level of functioning due to increased nitrogen immobilization and a decrease in its gaseous losses. The least resistance was exhibited by agrophytocenosis with the introduction of nitrogen fertilizers alone with an acidic reaction of the soil solution ( $\mathrm{pH} 5.0)$.

Table 3. Soil nitrogen fluxes in the agrophytocenosis of sugar beet upon acidification of chernozems, g/vessel.

\begin{tabular}{|l|c|c|c|c|}
\hline \multirow{2}{*}{\multicolumn{1}{|c|}{ Indicators }} & \multicolumn{2}{|c|}{$\mathrm{pH} \mathrm{5.0}$} & \multicolumn{2}{c|}{$\mathrm{pH} 6.5$} \\
\cline { 2 - 5 } & $\begin{array}{c}\text { Back- } \\
\text { ground } \\
+{ }^{15} \mathrm{~N}_{12}\end{array}$ & $\begin{array}{c}\text { Background } \\
+ \\
\mathrm{PBE}_{6}+{ }^{15} \mathrm{~N} \\
6\end{array}$ & $\begin{array}{c}\text { Back- } \\
\text { ground } \\
+{ }^{15} \mathrm{~N}_{12}\end{array}$ & $\begin{array}{c}\text { Background } \\
+ \\
\mathrm{PBE}_{6}+{ }^{15} \mathrm{~N} \\
6\end{array}$ \\
\hline Soil nitrogen uptake by plants & 8.89 & 17.71 & 18.50 & 22.47 \\
\hline Residual mineral nitrogen, g/m $\mathrm{m}^{2}$ & 3.50 & 2.70 & 3.10 & 2.50 \\
\hline Immobilized/reimmobilized nitrogen & 9.78 & 35.42 & 25.90 & 35.95 \\
\hline Gaseous nitrogen losses & 34.67 & 19.48 & 33.30 & 58.42 \\
\hline Mineralized nitrogen, M & 70.23 & 69.07 & 88.80 & 102.57 \\
\hline Net mineralized nitrogen, N-M & 50.67 & 46.05 & 57.35 & 65.13 \\
\hline Reimmobilized nitrogen, RN & 19.56 & 23.02 & 31.45 & 40.45 \\
\hline
\end{tabular}


Table 4. Indices of the integral assessment of the soil-plant system functioning when growing sugar beets with acidification of typical chernozem.

\begin{tabular}{|l|c|c|c|}
\hline \multicolumn{1}{|c|}{ Option } & RN:M,\% & N-M:RN,\% & Mode of operation \\
\hline \multicolumn{3}{|c|}{$\mathrm{pH} 5.0$} \\
\hline Background $+{ }^{15} \mathrm{~N}_{12}$ & 28 & 2.6 & Maximum permissible \\
\hline $\begin{array}{l}\text { Background }+\mathrm{PBE}_{6} \\
+{ }^{15} \mathrm{~N}_{6}\end{array}$ & 33 & 2.0 & Permissible \\
\hline \multicolumn{3}{|c|}{$\mathrm{pH} 6.5$} \\
\hline Background $+{ }^{15} \mathrm{~N}_{12}$ & 35 & 1.8 & Permissible \\
\hline $\begin{array}{l}\text { Background }+\mathrm{PBE}_{6} \\
+{ }^{15} \mathrm{~N}_{6}\end{array}$ & 39 & 1.6 & Permissible \\
\hline
\end{tabular}

Sugar beet formed the highest productivity on soil with a neutral $\mathrm{pH}$ value of 6.5 (Table 5). With the acidification of typical chernozem, the yield of root crops decreased by $30 \%$, and the yield of tops - by $24 \%$ compared to soil with a $6.5 \mathrm{pH}$.

Table 5. Sugar beet productivity under changing nutritional conditions and $\mathrm{pH}$ of typical chernozem.

\begin{tabular}{|c|c|c|c|c|c|c|}
\hline \multirow{3}{*}{ Option } & \multicolumn{3}{|c|}{ Root crops } & \multicolumn{3}{|c|}{ Tops } \\
\hline & \multirow{2}{*}{$\begin{array}{l}\text { Yield, g/ves- } \\
\text { sel }\end{array}$} & \multicolumn{2}{|c|}{ Increase } & \multirow{2}{*}{$\begin{array}{l}\text { Yield, } \\
\text { g/vessel }\end{array}$} & \multicolumn{2}{|c|}{ Increase } \\
\hline & & g/vessel & $\%$ & & g/vessel & $\%$ \\
\hline \multicolumn{7}{|c|}{$\mathrm{pH} 5.0$} \\
\hline $\mathrm{P}_{6} \mathrm{~K}_{6}-$ background & 364 & - & - & 76 & - & - \\
\hline Background $+{ }^{15} \mathrm{~N}_{12}$ & 666 & 302 & 83 & 178 & 102 & 134 \\
\hline Background $+\mathrm{PBE}_{6}+{ }^{15} \mathrm{~N}_{6}$ & 1156 & 792 & 118 & 190 & 114 & 150 \\
\hline $\begin{array}{l}\text { Background }+\mathrm{PBE}_{12} \\
\text { (equiv. to } \mathrm{N}_{12} \text { ) }\end{array}$ & 816 & 452 & 124 & 86 & 10 & 13 \\
\hline $\mathrm{P} \%$ & 3 & & & 2 & & \\
\hline $\mathrm{LSD}_{0.5}$ & 61 & & & 7 & & \\
\hline \multicolumn{7}{|c|}{ pH 6.5} \\
\hline $\mathrm{P}_{6} \mathrm{~K}_{6}-$ background & 387 & - & - & 102 & - & - \\
\hline Background $+{ }^{15} \mathrm{~N}_{12}$ & 1207 & 900 & 212 & 188 & 86 & 84 \\
\hline Background $+\mathrm{PBE}_{6}+{ }^{15} \mathrm{~N}_{6}$ & 1654 & 1267 & 327 & 239 & 137 & 134 \\
\hline $\begin{array}{l}\text { Background }+\mathrm{PBE}_{12} \\
\text { (equiv. to } \mathrm{N}_{12} \text { ) }\end{array}$ & 1325 & 938 & 242 & 114 & 12 & 12 \\
\hline $\mathrm{P} \%$ & 3 & & & 3 & & \\
\hline $\mathrm{LSD}_{0.5}$ & 98 & & & 14 & & \\
\hline
\end{tabular}

The use of effluent and nitrogen fertilizers influenced the productivity of sugar beets. The highest yield of root crops was formed by beets with the combined application of PBE and nitrogen mineral fertilizers (the intake efficiency amounted to $137 \%$ ). This was due to the better assimilation of fertilizer's nitrogen and soil nitrogen by plants. A decrease in the beet productivity with the introduction of effluent (the equivalent dose of mineral fertilizers' nitrogen) is associated with an increase in the immobilization of fertilizer nitrogen and soil nitrogen. In addition, acidification of chernozem ( $\mathrm{pH} 5.0)$ reduces the availability of mineral nitrogen to plants.

The formation of the carbohydrate-protein complex of beet root crops is closely related to the conditions of plants' mineral nutrition (Table 6). Under acidic medium conditions ( $\mathrm{pH}$ 5.0 ), fertilization increased the sugar content in root crops by $0.2-1.3 \%$, while at $\mathrm{pH} 6.5$ it decreased by $1.3-2.0 \%$ compared to the background. 
Table 6. Sugar content in sugar beet roots, $\%$.

\begin{tabular}{|c|c|c|c|c|}
\hline \multirow{2}{*}{ Option } & \multicolumn{2}{|c|}{$\mathrm{pH} 5.0$} & \multicolumn{2}{c|}{$\mathrm{pH} 6.5$} \\
\cline { 2 - 5 } & Content, $\%$ & Increase, \pm & Content, $\%$ & Increase, \pm \\
\hline $\mathrm{P}_{6} \mathrm{~K}_{6}$ - background & 17.3 & - & 18.4 & - \\
\hline Background $+{ }^{15} \mathrm{~N}_{12}$ & 18.6 & 1.3 & 16.6 & -1.8 \\
\hline $\begin{array}{c}\text { Background }+\mathrm{PBE}_{6}+ \\
{ }_{15} \mathrm{~N}_{6}\end{array}$ & 17.8 & 0.5 & 16.4 & -2.0 \\
\hline $\begin{array}{c}\text { Background }+\mathrm{PBE}_{12} \\
\text { (equiv. to } \mathrm{N}_{12} \text { ) }\end{array}$ & 17.5 & 0.2 & 17.3 & -1.3 \\
\hline LSD $_{0.5}$ & 0.3 & & 0.3 & \\
\hline
\end{tabular}

At pH 6.5 of the soil solution, the sugar content in root crops decreased by $0.2-2.0 \%$ compared to $\mathrm{pH}$ 5.0. A decrease in sugar content in beet root crops is caused by an increase in the amount of nitrate nitrogen in the soil by a factor of 2-3 due to the activity intensification of nitrifying microorganisms and their enzymatic systems.

\section{Conclusion}

Under the conditions of typical chernozem $\left(\mathrm{pH}_{\text {salt }}\right.$ of the soil solution 6.5$)$, sugar beet consumed the greatest amount of nitrogen $\left(25.78 \mathrm{~g} / \mathrm{m}^{2}\right)$ in the combined use of urea (labeled ${ }^{15} \mathrm{~N}$, $6 \mathrm{~g} \mathrm{~N} / \mathrm{m}^{2}$ ) and organic fertilizers (pig-breeding complex effluent, PBE in calculation $6 \mathrm{~g}$ $\mathrm{N} / \mathrm{m}^{2}$ ). When the soil was acidified to $\mathrm{pH} 5.0$, the consumption by beets decreased, \%: fertilizer's nitrogen - 15-18; soil nitrogen - 21-52; PBE nitrogen - 16.

The fertilizer's nitrogen consumption by plants with the effluent introduction decreased by $54-56 \%$, while the assimilation of soil nitrogen by beets increased at $\mathrm{pH} 5.0$ by $99 \%$ and at $\mathrm{pH} 6.5$ - by $21 \%$ compared with the use of mineral nitrogen fertilizers.

With the acidification of chernozem to $\mathrm{pH} 5.0$, the immobilization of nitrogen in the fertilizer decreased by $13-18 \%$, and the formation of gaseous nitrogen-containing compounds increased by $47-108 \%$. The use of PBE (together with nitrogen fertilizers) activated the immobilization of fertilizer's nitrogen (by $38-46 \%$ ) and inhibited gaseous nitrogen losses (by $22-44 \%)$.

The highest stable functioning of the agrophytocenosis provided the best utilization by plants, the highest immobilization/reimmobilization of soil nitrogen - at $\mathrm{pH} 6.5$. The acidification of chernozem to $\mathrm{pH} 5.0$ reduced the stability of the system by $15-20 \%$ in terms of $\mathrm{RN}: \mathrm{M}$ and by $25-44 \%$ in terms of N-M:RN. The introduction of effluent increased the resistance of agrophytocenosis by $18-30 \%$ at $\mathrm{pH} 5.0$ and by $11-12 \%$ at $\mathrm{pH} 6.5$.

Acidification of chernozem leads not only to a decrease in the resistance of agrophytocenosis, but also to its productivity. When the $\mathrm{pH}$ was lowered to 5.0, the yield of root crops decreased by $30 \%$, and the yield of tops - by $24 \%$, compared to soil with a $\mathrm{pH}$ of 6.5 . The highest yield of root crops (1654 g/vessel) and tops ( $239 \mathrm{~g} / \mathrm{vessel})$ was formed by sugar beet with the combined application of effluent and nitrogen fertilizers.

Under acidic environmental conditions ( $\mathrm{pH}$ 5.0), fertilization introduction increased the sugar content in beet root crops by $0.2-1.3 \%$, while at $\mathrm{pH} 6.5$ it decreased by $1.3-2.0 \%$ compared to the background.

\section{References}

1. S.V. Lukin, Eurasian Soil Science, 50(11), 1323-1331 (2017) DOI: $10.1134 / \mathrm{S} 1064229317110096$. 
2. S.V. Lukin, D.V. Zhuikov, I.G. Kostin, E.A. Prazina, A.A. Zavalin, V.A. Chernikov, EurAsian Journal of Bio- Sciences, 13(2), 877-881 (2019)

3. S.V. Lukin, S.V. Selyukova, V.A. Chernikov, N.A. Gaitova, Pollution Research, 39(2), 196-201 (2020)

4. S.V. Lukin, D.V. Zhuikov, Eurasian Soil Science, 54(1), 63-71 (2021) DOI: 10.1134/S1064229321010099.

5. V.G. Sychev, The main indicators of crop yields and their relationship, 228 (2003)

6. V.G. Sychev, O.A. Sokolov, N.Ya. Shmyreva, The role of nitrogen in the intensification of the production process of agricultural crops. Agrophysical aspects of the role of nitrogen in the production process, 1, 424 (2009)

7. A.Kh. Kulikova, E.A. Yashin, E.V. Danilova, Agrochemistry, 6, 27-31 (2007)

8. T.R. Denk, J. Mohn, C. Decock, Soil. Biol. Biochem, 105, 121-137 (2017)

9. M. Fried, L. Dean, Soil Sci., 13(4), 263-271 (1952)

10. F.V. Turchin, Magazine WMO, 10(4), 400-401 (1965)

11. L.V. Pomazkina, Agrochemistry of nitrogen in the taiga zone of the Baikal region, 176 (1985)

12. Sugar beet. Analysis methods State standard 53036-2008.

13. P.M. Smirnov, Agrochemistry of nitrogen, 72 (1977)

14. N.M. Varyushkina, M.V. Nikiforova, M.M. Nikitina, Bulletin of the All-Russian Scientific Research Institute of Agrochemistry named after D.N. Pryanishnikov, 45, 18-25 (1979)

15. V.M. Semenov, Agrochemistry, 1, 78-96 (2020)

16. E. Inselsbacher, W. Wanek, J. Strauss, Soil Biol. Biochem., 57, 301-310 (2013)

17. T. Klein Becker, N. Holzel, D. Prati, J. Ecology, 102, 456-465 (2014)

18. N. Arens, A. Backhaus, S. Doll, Front Plant Sci., 7, 1377 (2016) 